\title{
APOE: The New Frontier in the Development of a Therapeutic Target towards Precision Medicine in Late-Onset Alzheimer's
}

\author{
Anna Yang ${ }^{1}$, Boris Kantor ${ }^{2,3,4}$ and Ornit Chiba-Falek 1,5,*(D) \\ 1 Division of Translational Brain Sciences, Department of Neurology, Duke University Medical Center, \\ Durham, NC 27710, USA; anna.yang569@duke.edu \\ 2 Department of Neurobiology, Duke University Medical Center, Durham, NC 27710, USA; \\ boris.kantor@duke.edu \\ 3 Viral Vector Core, Duke University Medical Center, Durham, NC 27710, USA \\ 4 Duke Center for Advanced Genomic Technologies, Durham, NC 27708, USA \\ 5 Center for Genomic and Computational Biology, Duke University Medical Center, Durham, NC 27708, USA \\ * Correspondence: o.chibafalek@duke.edu
}

Citation: Yang, A.; Kantor, B.; Chiba-Falek, O. APOE: The New Frontier in the Development of a Therapeutic Target towards Precision Medicine in Late-Onset Alzheimer's. Int. J. Mol. Sci. 2021, 22, 1244. https://doi.org/10.3390/ijms22031244

Academic Editor: Cristoforo Comi Received: 31 December 2020

Accepted: 23 January 2021

Published: 27 January 2021

Publisher's Note: MDPI stays neutral with regard to jurisdictional claims in published maps and institutional affiliations.

Copyright: (c) 2021 by the authors. Licensee MDPI, Basel, Switzerland. This article is an open access article distributed under the terms and conditions of the Creative Commons Attribution (CC BY) license (https:// creativecommons.org/licenses/by/ $4.0 /)$.

\begin{abstract}
Alzheimer's disease (AD) has a critical unmet medical need. The consensus around the amyloid cascade hypothesis has been guiding pre-clinical and clinical research to focus mainly on targeting beta-amyloid for treating AD. Nevertheless, the vast majority of the clinical trials have repeatedly failed, prompting the urgent need to refocus on other targets and shifting the paradigm of AD drug development towards precision medicine. One such emerging target is apolipoprotein $\mathrm{E}(A P O E)$, identified nearly 30 years ago as one of the strongest and most reproduceable genetic risk factor for late-onset Alzheimer's disease (LOAD). An exploration of APOE as a new therapeutic culprit has produced some very encouraging results, proving that the protein holds promise in the context of LOAD therapies. Here, we review the strategies to target APOE based on state-of-the-art technologies such as antisense oligonucleotides, monoclonal antibodies, and gene/base editing. We discuss the potential of these initiatives in advancing the development of novel precision medicine therapies to LOAD.
\end{abstract}

Keywords: APOE; Alzheimer's disease; late-onset; gene therapies; antisense oligonucleotides; monoclonal antibodies; gene editing; base editing; beta-amyloid; neurodegenerative disease

\section{Introduction}

Alzheimer's disease (AD) is the most common age-related neurodegenerative disease (NDD). Age is the leading risk factor for AD; thus, with a rapidly growing aging population, the number of $\mathrm{AD}$ cases is growing fast and projected to rise drastically over the next three decades. In the US alone more than 5 million people are currently living with $\mathrm{AD}$ and this number is projected to reach 14 million cases by 2050. As a consequence, $\mathrm{AD}$ poses a huge economic burden on society, placing overwhelming strain on the healthcare system. In 2020 , the cost of AD to the US was \$301 billion, including \$206 billion in Medicare and Medicaid payments, and caregivers provided $\$ 244$ billion worth of care [1]. These trends will worsen because there are no therapies to halt or prevent $\mathrm{AD}$, projected to cost more than $\$ 1.1$ trillion annually by 2050. Despite all the research effort, money, and commitment, there is no cure for $\mathrm{AD}$, nor any disease-modifying therapies (DMT) to slow down or even delay the progression of the disease. The current treatments are mostly palliative aimed at improving symptoms management rather than curing the disease. To date, there are only five FDA-approved drugs available for $\mathrm{AD}$, three of which are cholinesterase inhibitors (donepezil, rivastigmine, and galantamine) [2], the fourth being an $\mathrm{N}$-methyl-D-aspartate (NMDA) receptor antagonist [3], and the fifth a combination of cholinesterase inhibitor and NMDA-receptor antagonist.

As mentioned above, these drugs may only provide some level of symptomatic relief for the patients, and numerous clinical trials to identify disease-modifying therapies (DMT) 
for AD have failed. Thus, AD remains an unmet medical need. Nonetheless the mainstream research for $\mathrm{AD}$ therapies continues to be based on the amyloid cascade hypothesis and, as such, the leading molecular target has been for decades the beta-amyloid isoforms $(A \beta)$, the cleavage product of the amyloid precursor protein (APP) [4] (Figure 1). These clinical trials are aimed at decreasing the levels of $A \beta$ aggregates and plaques using drugs that reduce production and aggregation and/or increase clearance of $A \beta$. Unfortunately, such trials have repeatedly failed, underscoring the lack of mechanistic understanding of $\mathrm{AD}$ pathogenesis and the urgent need for a paradigm shift in AD clinical research. While these failures have driven researchers to initiate clinical trials earlier in the course of the disease, with the concept that earlier intervention might be more effective, another major reason for the failure to identify an effective treatment is likely the inaccurate consideration of $\mathrm{AD}$ as a homogeneous disease. In this respect, increasing evidence demonstrates the heterogeneity in the underlying pathophysiologic processes of $\mathrm{AD}$ and show variability in the genetic risk and molecular profiles amongst AD patients $[5,6]$.

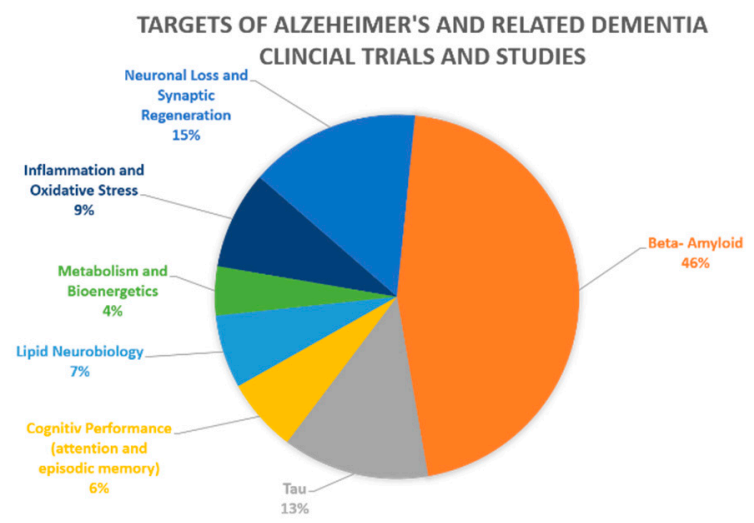

Figure 1. Clinical trials and studies for Alzheimer's and related dementia by drug targets. The figure represents the 46 current pharmacological NIA-funded active Alzheimer's and related dementias clinical trials and studies. The different molecular/pathways targets are color coded, with their percentage from all current clinical studies indicated. Beta-amyloid is the target of $46 \%$ of the studies, tau and neuronal loss follow far behind with respective percentages of $13 \%$ and $15 \%$ [7].

Collectively, advancement in $\mathrm{AD}$ therapy requires the development and validation of new therapeutic targets, including drug targets tailored to sub-group/s of patients with specific risk factors. Thus, to date many investigators and funding bodies recognize the need to shift the focus to potential culprits other than $A \beta$. Consistently, recently, alternative targets, such as $A P O E$, have emerged as potential promising targets for $\mathrm{AD}$ treatment [8-10]. Nonetheless, the development of $A P O E$ as a new drug target moves at a slower pace compared to the continuing clinical research related to $A \beta$. Of the 46 current pharmacological NIA-funded active Alzheimer's and related dementias clinical trials and studies, $46 \%$ of the studies continue to focus on $A \beta$ as their target, with tau and neuronal loss as targets following far behind with respective percentages of $13 \%$ and $15 \%$, as seen in Figure 1. The remaining targets altogether account for less than $26 \%$ of current clinical trials, with currently no active clinical trials targeting APOE [7]. This review is focused on $A P O E$, the most established risk factor for late-onset $\mathrm{AD}$ (LOAD) [11], as a potential therapeutic target for $\mathrm{LOAD}$ towards precision medicine in $\mathrm{AD}$. We describe the evidence supporting $A P O E$ as a promising target and, in particular, the new research initiatives that have been developed to target the $A P O E$ gene and protein product, namely, antisense oligonucleotide (ASO), monoclonal antibody (mAbs), and gene editing approaches. 


\section{The APOE Locus Is the Strongest Genetic Risk for LOAD}

\subsection{ApoE Protein: Function and Isoforms}

The apolipoprotein E protein (ApoE) has multiple functions and plays key roles in lipid metabolism, neurobiology, and neurodegenerative diseases. Its major function is to transport lipids among various cells and tissues of the body. In addition, intracellular ApoE may modulate various cellular processes physiologically or pathophysiologically, including cytoskeletal assembly and stability, mitochondrial integrity and function, and dendritic morphology and function [12]. Overall, ApoE is widely involved in human health and disease.

ApoE is encoded by the APOE gene positioned on chromosome 19q13.32 (GRCh 38: chr19:44,905,795-44,909,392). Two common coding SNPs in exon 4 of the gene give rise to three allelic variants, $A P O E \mathrm{e} 2, A P O E \mathrm{e} 3$, and $A P O E \mathrm{e} 4$, encoding three corresponding protein isoforms that differ at two amino acid positions, 112 and 158: ApoE2 (Cys ${ }^{112}$; $\left.\mathrm{Cys}^{158}\right)$, ApoE3 (Cys $\left.{ }^{112} ; \mathrm{Arg}^{158}\right)$, and ApoE4 ( $\mathrm{Arg}^{112}$; $\left.\mathrm{Arg}^{158}\right)$. It was suggested that the single amino acid change (position 112) between the ApoE3 to ApoE4 protein isoforms resulted in structural differences that involve the interactions between sequences from both the N- and C-terminal domains [13,14] (Figure 2A).

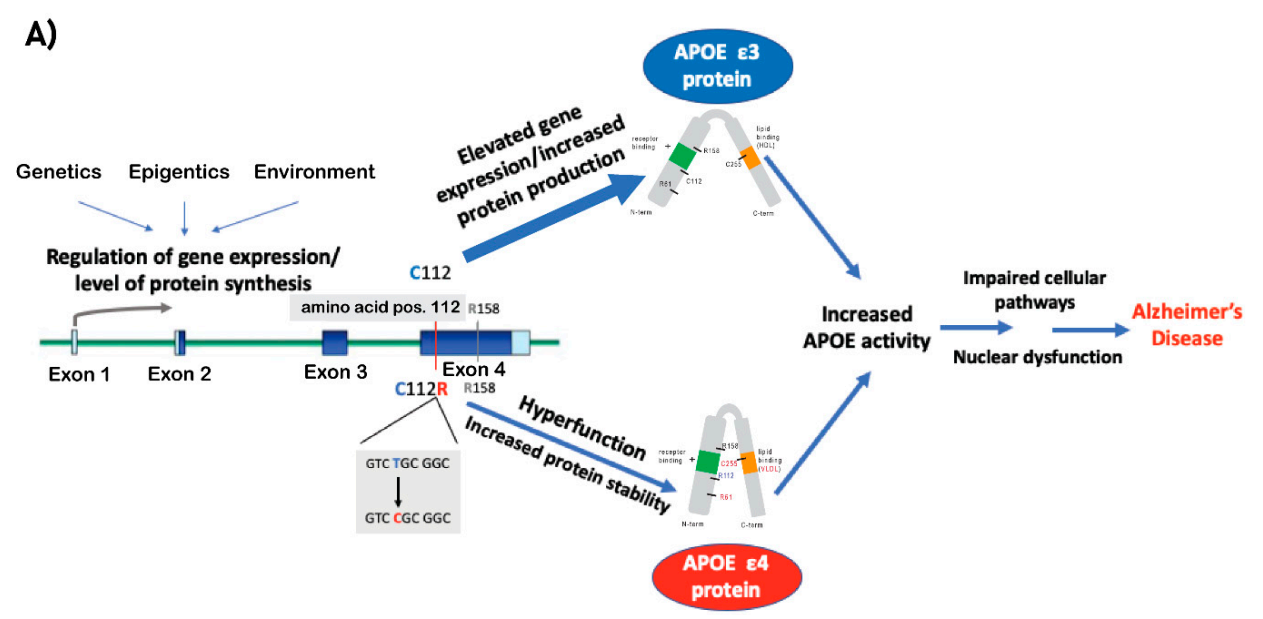

B)

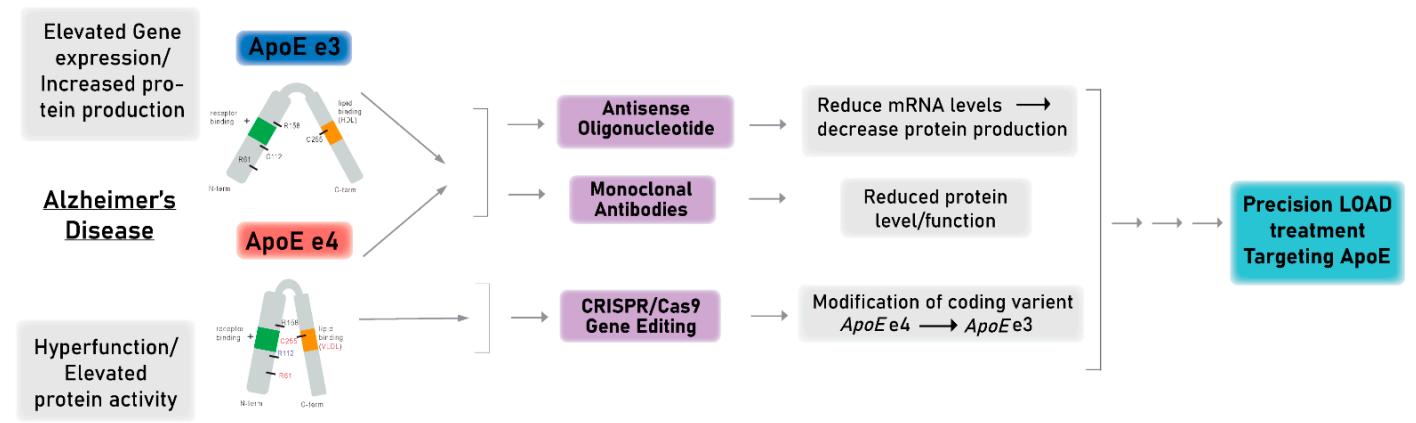

Figure 2. (A) A schematic model describing the mechanisms that lead to increased ApoE activity and by that mediate the pathogenic effect of APOE e4 and APOE e3 (differ in amino acid at position 112 Arg and Cys, respectively) on LOAD. Coding exons designated in blue boxes, UTRs in light blue, introns in green lines. (B) A diagram of the different technologies described in this review to target ApoE, including antisense oligonucleotide (ASO), monoclonal antibody (mAbs), and CRISPR/Cas9 gene editing technologies. The ultimate goal of the presented methods is to establish a proof-of-concept for the development of precision medicine treatments for LOAD by targeting ApoE and correcting its coding sequence or reducing its production. Purple boxes represent the therapeutic approaches, gray boxes represent how APOE mediates its the pathogenic effects (left) and the outcomes of the therapeutics approaches with respect to APOE (right). 


\subsection{APOE e4}

The first and most firmly established genetic risk factor for LOAD is the e4 allele of the apolipoprotein E gene (APOE e4) [15-18]. The initial discovery was made nearly 30 years ago by linkage analysis of pedigrees [15] and over the ensuing years it has become the most highly replicated genetic risk factor [15-18]. Carrying the APOE e4 variant significantly increases the lifetime risk for LOAD, whereas the number of e4 copies affects the level of risk and is associated with the age of clinical disease onset [15,19], while APOE e2 conferred a protective effect [18-20]. Although the precise molecular mechanisms underlying ApoE e4mediated risk effects have not been fully elucidated, it was suggested that ApoE e4 acquired hyperfunction (gain of toxic effects) [21] and increasing data suggested several cellular pathways through which ApoE e4 may exert toxicity associated with LOAD pathologic phenotypes [22-28]. Collectively, these studies provide strong support to the concept that decreasing the levels of ApoE e4 specifically will have a therapeutic implication. However, ApoE e4 as a target for LOAD still remains significantly understudied, despite the few recent studies that have begun to pave the way.

\subsection{Dysregulation of APOE Expression}

Over the last decade, LOAD genome-wide association studies (GWAS) have confirmed strong associations with the APOE LD genomic region, and no other LOAD-association remotely approached the same level of significance [29-37]. Although some LOAD GWAS exclude all variants in this region, because of their high LD with the coding SNPs that define the APOE genotype $(\mathrm{e} 2,3,4)$, other LOAD genetic studies have focused on the association between variants and haplotypes based on the promoter and enhancer regions of genes in this region and LOAD phenotypes [38-45]. However, whether the strongest signal is attributed to additional variants and haplotypes within this LD region jointly with e4, as well as the molecular mechanisms underlying the LOAD-association with the APOE LD region, is largely unknown.

Accumulating new evidence has suggested that the increased overall expression of APOE plays an important role in the etiology of LOAD (reviewed in [21]). Foremost, previously we found significant higher levels of APOE-mRNA in brain tissues obtained from e3/3 LOAD patients compared to $3 / 3$ healthy donors, consistently with other reports showing elevated levels of APOE-mRNA in LOAD brains [46-49]. In addition, new singlenucleus (sn)RNA-seq datasets showed LOAD changes in APOE expression in glia cell-types, in particular upregulation in microglial subpopulations [50-52]. Moreover, studies using the APP/PS1 transgenic mice showed that lowering the ApoE protein levels ameliorated cognitive dysfunctions and A $\beta$ pathology [53] independent of the APOE allele [8,54,55]. Lastly, studies showed LOAD associated differential DNA-methylation [56-60], further supporting that dysregulation of APOE expression plays a role in the genetic etiology of LOAD. In conclusion, while ApoE4 has received much attention for its LOAD-risk effect, there are clear changes in APOE expression associated with LOAD and independent of the e4 allele [8], suggesting that regulation of APOE expression may impact the risk to develop LOAD, making the modulation of the overall ApoE protein levels useful as a future therapeutic target.

Based on the evidence presented above, we postulate that the e4 allele's inherent hyperfunction, by which it exerts its pathogenic effect, is comparable to the plausible pathogenic effect of elevated e3 expression. Thus, increased activity of ApoE, mediated by either a coding mutation in exon 4 and/or gene dysregulation, is the key role of APOE in the genetic etiology of LOAD (Figure 2A). Thus, methods for modifying the e4 isoform and/or reducing APOE levels introduce a new promising avenue towards precision medicine in LOAD (Figure 2B).

Noteworthy, APOE e2 has been identified as a longevity variant, associated with beneficial effects on cognition, and accumulating evidence suggested it protects against $\mathrm{AD}$ (reviewed in [61]). While the mechanisms driving its protective effect remain unclear, potential therapeutic strategies designed to leverage the protective effect of APOE e2, such 
as viral-mediated overexpression of APOE e2 and gene-editing conversion of APOE e4 to e2, hold promise as treatment options for AD. With that said, APOE e2 increases the risk of other diseases, including neurological disorders; thus, long-term safety concerns should be carefully evaluated when considering treatments inspired by the protective role of e2 in AD. This topic has been extensively reviewed elsewhere [61,62] and is outside the scope of this review.

In the current review we focus on therapeutics strategies designed to mitigate the risk of LOAD conferred by the APOE gene (as proposed in Figure 2A). Below we describe three major technologies aimed at targeting the APOE gene, transcript, or protein, which may serve as a proof-of-concept for prospective therapeutics approaches (Figure 2B).

\section{Technologies for Targeting APOE as a Proof-of-Concept for LOAD Therapies}

\subsection{Antisense Oligonucleotide Therapy}

\subsubsection{ASO Technology and Application in Disease Therapy}

Antisense oligonucleotides (ASOs) are short, single-stranded deoxyribonucleotides, typically consisting of about 25 nucleotides. ASOs are synthetically designed to be complementary and capable of hybridizing to specific mRNA strands [63], such that they can modify the expression of mRNA using either a splice modulation or knockdown approach, as determined by the target and design chemistry [64]. The ASO approach aims at downregulation of the production of the disease-causing protein by recognizing the particular RNA molecule target from which the protein is translated (Figure 3). ASOs are a promising therapeutic technology because of their rapid and highly selective capabilities to target and destroy a specific RNA molecule based on its sequence. However, there are few shortcomings for ASO as a therapeutics approach; foremost, effective ASO delivery methods for the CNS remain a challenge, as ASOs lack the ability to penetrate the blood-born barrier (BBB) efficiently [65]. Another concern is the possibility of adverse side effects due to ASO-induced cellular toxicities and off-target effects in both sequence- and chemistrydependent manners [65]. In addition, the potential robust knockdown mediated by ASOs can be deleterious, resulting in a deficiency in the normal physiological levels of the target protein that is needed to maintain normal biological processes and cellular function. For example, RNAi studies reported neurotoxicity associated with a robust reduction in the SNCA levels [66,67], and suggested the need to maintain normal physiological expression levels of the SNCA protein.

ASOs are currently being used as a possible successful treatment method for several diseases. For example, the ASO-based drugs Etepliersen and Golodirsen, used to treat Duchenne muscular dystrophy (DMD), were approved in the US in 2016 and 2019, respectively. DMD results from a mutation in the gene encoding the protein dystrophin, resulting in a shorter and prematurely truncated protein with a deletion of exon 49 and 50. Etepleirsen acts by using a morpholino ASO for exon skipping purposes, ultimately excluding exon 51 and leading to a restored reading frame and leaving a more functional dystrophin protein [64]. Similarly, Golodirsen also utilizes ASO to perform exon skipping by hybridizing with DMD pre-mRNA and skipping exon 53 leading to the production of a shorter, but functional dystrophin protein [68]. Another example is the drug Nusinersen, approved by the FDA in 2016 and by the European Commission Agency in 2017, for treating certain forms of spinal muscular atrophy (SMA) [64]. SMA, a neuromuscular disorder, is caused by loss of function mutations or deletions of the survival motor neuron 1 (SMN1) gene. Nusinersen acts to enhance the production of functional SMN protein encoded by the highly homologous gene SMN2. The SMN2 gene naturally exhibits aberrant splicing of exon 7, resulting in a truncated and unstable protein. The ASO targets SMN2 pre-mRNA to induce the correct splicing, leading to increased levels of the full length SMN protein. This ASO therapy demonstrated significant improvement in motor function of treated children when compared to sham procedures [69]. There are also several ASO therapies in early phase clinical trial testing. An example is the drug targeting HTT in Huntington's disease, which use ASO to decrease the levels of the mutant huntingtin protein (mHTT) [70,71]. 
Another example is ASO developed to target superoxide dismutase 1 (SOD1) for the treatment of amyotrophic lateral sclerosis (ALS) [64]. Mutations in SOD1 are responsible for $\sim 20 \%$ of familial ALS, leading to the gain of toxic function. ASOs for SOD1 decreased the protein levels and extended survival in rat models [72], and showed beneficial outcomes by reducing the SOD1 levels in a Phase 1 clinical trial [73].

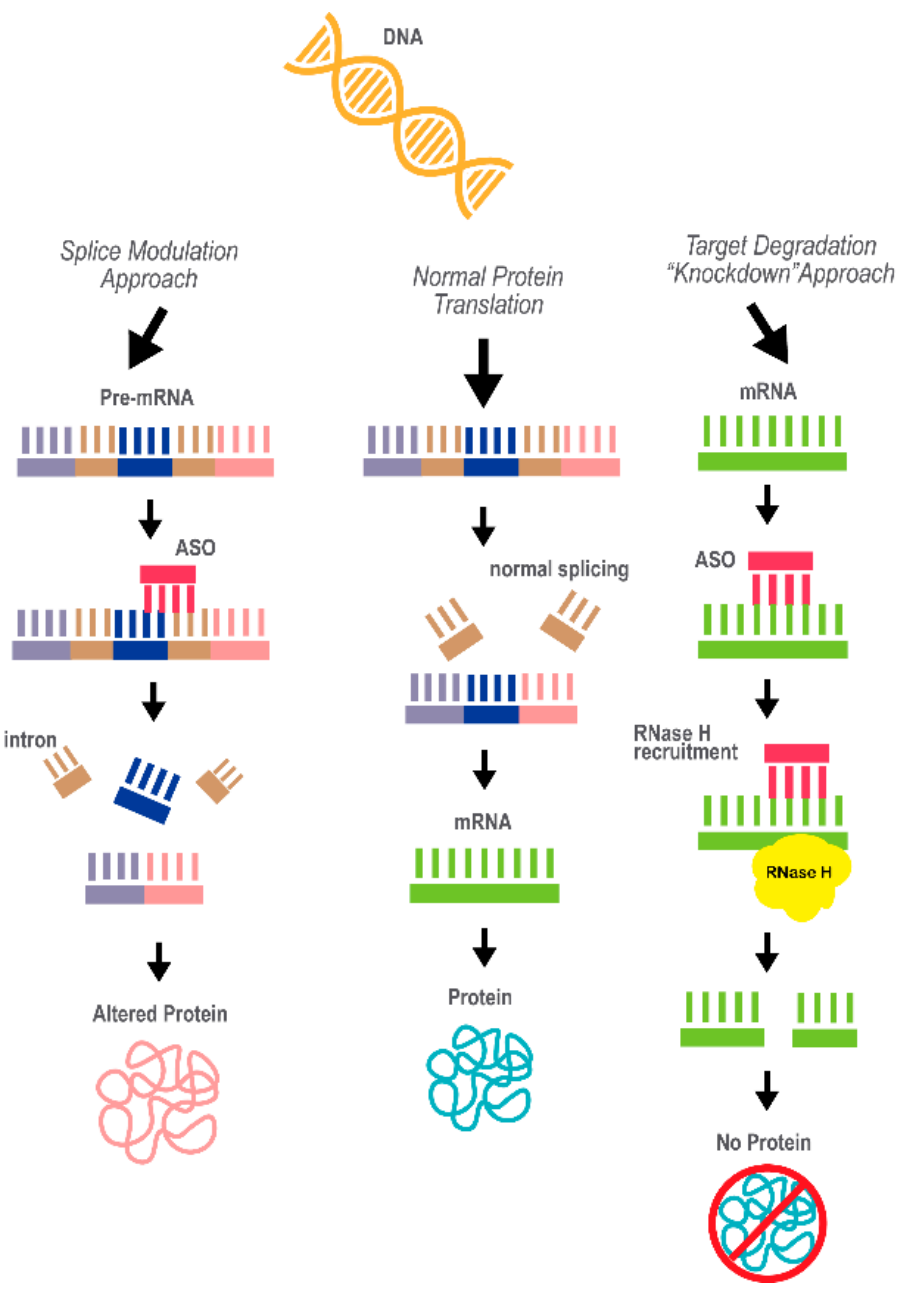

Figure 3. A diagram of the concept behind antisense oligonucleotide (ASO) technology as a therapeutic approach. The two mechanisms underlying the ASO effects, splice modulation and target degradation ("knockdown"), are depicted. The ASO is marked in red. Purple, dark blue and pink represent different exons of the pre-mRNA; brown represents introns; green represent the processed mRNA (the product of correct splicing)

\subsubsection{Current Progress in ASO Therapy Targeting APOE}

ASO to reduce APOE expression was applied in a study using a mouse model of beta-amyloidosis, the APP/PS1-21 transgenic, homozygous for either the APOEe4 or $A P O E \mathrm{e} 3$ alleles. The ASO treatment decreased the APOE-mRNA and protein levels in the mice brains by at least $50 \%$ compared to the controls. The investigators examined the effect of the ASO treatment on phenotypes related to A $\beta$ pathology, characteristics of the APP/PS1-21 model [8]. The authors reported age-dependent effects on reversing the $\mathrm{A} \beta$ phenotypic perturbations. ASO treatment starting after birth led to a significant decrease in $A \beta$ pathology when assessed at 4 months, while ASO treatment starting later at the onset of amyloid deposition (6 weeks) showed an increase in $A \beta$ plaque size with no change in overall $A \beta$ burden. On the other hand, both age groups demonstrated a reduction in plaque-associated neuritic dystrophy upon ASO treatment [8]. These overall results suggest that the $A P O E$ levels may play an important role in the earlier stages of 
$A \beta$ plaque formation but has a more limited effect once the $A \beta$ pathology has already begun. Thus, since AD pathology begins prior to clinical symptom onset, the treatment aims to reduce $A P O E$ such that ASO may be most effective in the earlier pre-symptomatic stages [8]. Noteworthy, the ASO effect on the A $\beta$ pathology, mediated by the reduction in $A P O E$ levels, was independent from the allele type and was detected in both e3 and e4 mice [8]. The observation that lowering the overall $A P O E$ level has beneficial effects, regardless of the allelic isoform, is consistent with the hypothesis we presented in Figure 2. Collectively, this study provides the foundation for the development of an ASO treatment aimed at reducing APOE expression to combat LOAD.

\subsection{Monoclonal Antibody Therapy}

\subsubsection{Monoclonal Antibody ( $\mathrm{mAb}$ ) Approach and Application in Disease Therapy}

Monoclonal antibody (mAb) therapies designed to target certain cells (e.g., cancer cells) or proteins. The mAbs were developed to target specific protein epitopes and resulted in the deactivation of the protein-of-interest via blocking the protein function (e.g., occupying the ligand-receptor binding site) and/or recruiting the immune system, which, in turn, activates protein degradation pathways, leading to decreased levels of the targeted protein or proteins complex (Figure 4). Most mAb therapy applications utilize direct protein delivery [74]. However, mAbs can be paired with virus-mediated gene transfer, e.g., using adeno-associated (AAV) or lentiviral (LV) vectors or a non-viral delivery route by RNA or DNA expression plasmids [75]. In the case of non-direct delivery (viruses, plasmids), antibody sequences will be inserted and administered to the host cell, and antibody production will occur [76] (Figure 4). Antibody therapy has several strengths, including a well-established protocol-of-delivery and route of administration, ability to cross the blood-brain barrier (BBB), interacts with the immune system, has a long half-life, and their ability to target precise locations, which ultimately makes the viral vectors an efficient delivery vehicle $[77,78]$. However, there are several shortcomings that characterize antibody-based therapies, including a high-level of immune response, low specificity, low stability and solubility [79], and usually requires repetitive injections in order to achieve therapeutic/correction levels [80].

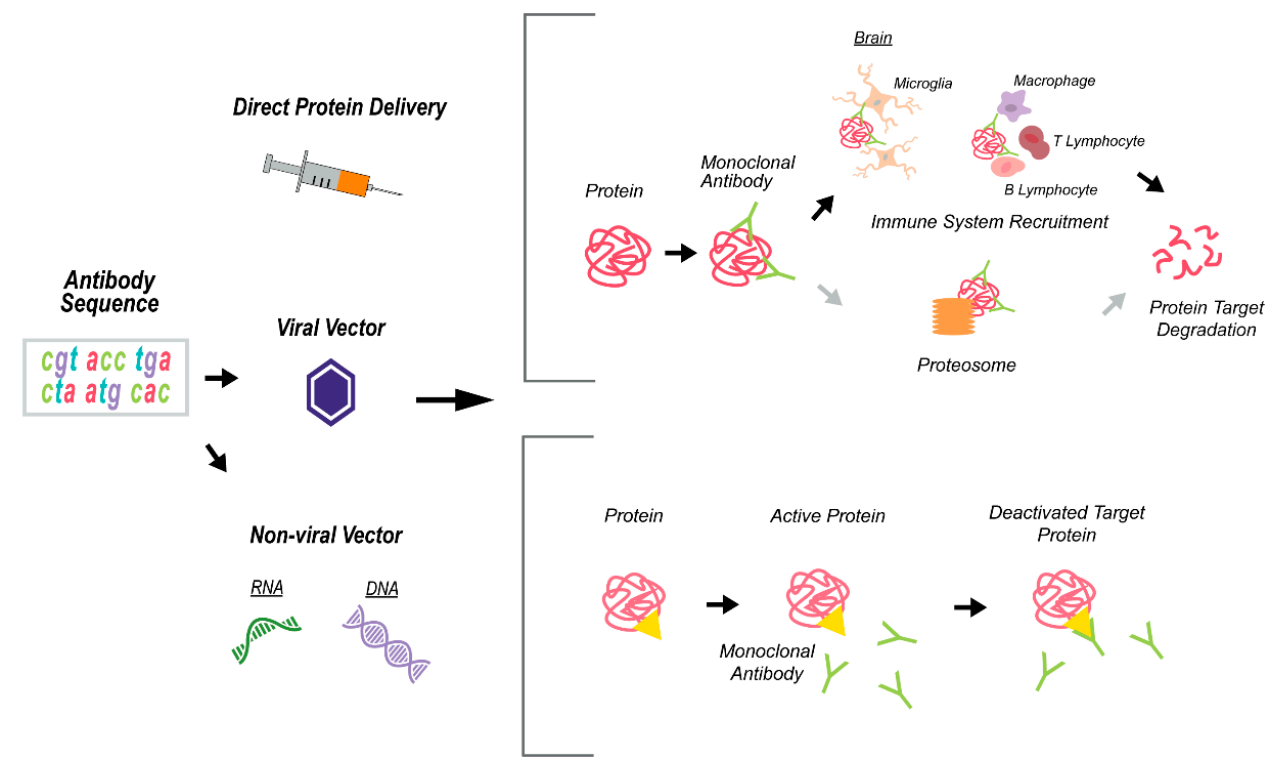

Figure 4. A schematic depicting the monoclonal antibody (mAb) technology for immunotherapies. Antibody delivery is done directly or through viral or non-viral vectors that contain the antibody sequence. The $\mathrm{mAb}$ specifically recognizes the target protein/s and exerts its effects via blocking the protein function (e.g., yellow triangle represents the ligand-receptor binding site) or by recruiting the immune system and activating protein degradation pathways. 
Monoclonal antibody therapies have been used successfully to treat many immunerelated diseases, such as cancer and inflammatory diseases [81]. Clinical trials are ongoing for the use of mAbs in processes such as transplant rejection, rheumatoid arthritis, and prevention of viral infection [75]. The use of $\mathrm{mAbs}$ in this respect has been studied since the 1990s and has seen much success, and is frequently used successfully in drugs such as infliximab [82].

$\mathrm{mAb}$-based treatment has also been developed to target the proteins that form aggregates in neurodegenerative proteinopathies, including Parkinson's disease (PD) and AD. In $\mathrm{PD}, \alpha$-synuclein protein undergoes a conformational change, resulting in the formation of Lewy bodies, the neuropathological hallmark of PD [83]. Several anti- $\alpha$-synuclein antibodies are being tested in clinical trials for their potential to target Lewy bodies and ameliorate their effects on PD progression; for example, PRX002 using the humanized anti- $\alpha$-synuclein monoclonal antibody $9 \mathrm{E} 4[84,85]$ and the anti- $\alpha$-synuclein antibody BIIB052 $[86,87]$. Several anti- $\beta$-amyloid antibodies have also been studied in clinical trials. Solanezumab by Eli Lilly and Company showed a non-significant slowing of cognitive decline and no effect on $\beta$-amyloid and was discontinued after Phase $3[88,89]$. Another $\beta$-amyloid antibody currently in Phase 3 testing is Crenezumab [90,91].

The most recent example of anti- $\beta$-amyloid antibodies is seen in Aducanumab developed by Biogen. Aducanumab is a human-derived monoclonal antibody that targets $\beta$-amyloid aggregates [92] by binding preferentially to the $\beta$-amyloid plaques rather than monomers, such that the monomer form remains available for potential neuroprotective functions [93]. Aducanumab completed its Phase 3 parallel-group studies EMERGE and ENGAGE in 2015. However, the two studies were abandoned in 2019 following a futility analysis of an independent monitoring committee. A larger dataset analysis later found that, of the two cohorts, the EMERGE data did meet its primary endpoint [94], with those treated with the higher doses of Aducanumab showing a reduction in $\beta$-amyloid plaques and a $23 \%$ reduction in cognitive decline [94]. However, the FDA decided not to recommend Aducanumab for regulatory approval in November of 2020 stating that the Phase 3 trial did not provide enough evidence of the drug's effectiveness in treating AD [95].

\subsubsection{Monoclonal Antibodies Targeting ApoE}

Several groups have evaluated anti-apoE immunotherapy as a method to rescue the pathological and behavioral features of AD. A passive immunization with the HJ6.3 apoE monoclonal antibody, before plaque onset, resulted in a $60-80 \%$ reduction in $A \beta$ accumulation in the cortex and hippocampus of an APP/PS1 mouse model [10]. The effects of treatment with the anti-ApoE antibody HJ6.3 on measures for learning and memory and on $A \beta$ pathology were also evaluated in the mice after the onset of $A \beta$ plaques deposition. This study showed that the anti-ApoE antibody HJ6.3 prevented the formation of new plaques, inhibited $\mathrm{A} \beta$ plaque growth, and improved brain function [96]. Moreover, administration of this antibody led to changes in microglia responses in areas around the $\mathrm{A} \beta$ plaques and showed that the anti-apoE antibodies bind to ApoE in plaques and activated microglia [10]. These results suggested that treatment with anti-ApoE may activate microglia-mediated clearance of the $A \beta$ aggregates $[9,10]$. While this study did not detect any influence on brain ApoE and peripheral cholesterol metabolism, we cannot exclude the possibility that the $\mathrm{mAb}$ treatment reduced the ApoE activity that is essential for $A \beta$ aggregation.

Another study examined ApoE antibody therapy utilizing an antibody that recognizes specifically the ApoE4 isoform, anti-ApoE4 9D11. Peripheral injection showed that the 9D11 monoclonal antibody inhibited the accumulation of $A \beta$ in the hippocampus [97]. Furthermore, repeated 9D11 injections showed the formation of ApoE/IgG complexes that reversed the cognitive impairments compared to the control ApoE4 mice, indicating a potential reversal of cognitive impairment [97]. Another study applied the anti-human ApoE4 antibody (HAE-4), targeting the nonlipidated aggregated ApoE before plaque onset 
also found a reduction in A $\beta$ pathology characteristic of the APPS1-21/humanAPOE4 mice [98].

Overall, these studies showed that anti-ApoE monoclonal antibodies have consistent effects on decreasing the $\mathrm{A} \beta$ plaque load and generally improves cognitive abilities, suggesting that anti-ApoE immunotherapy is a promising therapeutics approach for LOAD.

\subsection{Gene Editing}

\subsubsection{Applications of Gene Editing in Disease Therapy}

The process of gene editing offers the ability to remove, revise, or replace a certain disease-causing gene mutation with a healthy copy of the gene at the DNA level and can provide durable and stable benefits by introducing precise changes to the DNA sequence directly to target cells [99]. The CRISPR-Cas9 system and its modifications (e.g., Cas variants such as deactivated Cas9) have been the mainstream in gene-editing research, including research aiming at the development of clinical applications [99] (Figure 5). While the breakthrough technology of genome editing brings profound therapeutics opportunities to treat, cure, and prevent genetic diseases, there are challenges that affect the translation into clinical applications. At present, the major hindering aspects of therapeutics genome editing include accuracy (off-target events), precision (undesired genomic sequence change), safety (e.g., immunogenicity), efficacy, efficient delivery systems, and extreme costs. The opportunities and challenges have been recently reviewed in detail elsewhere [100].
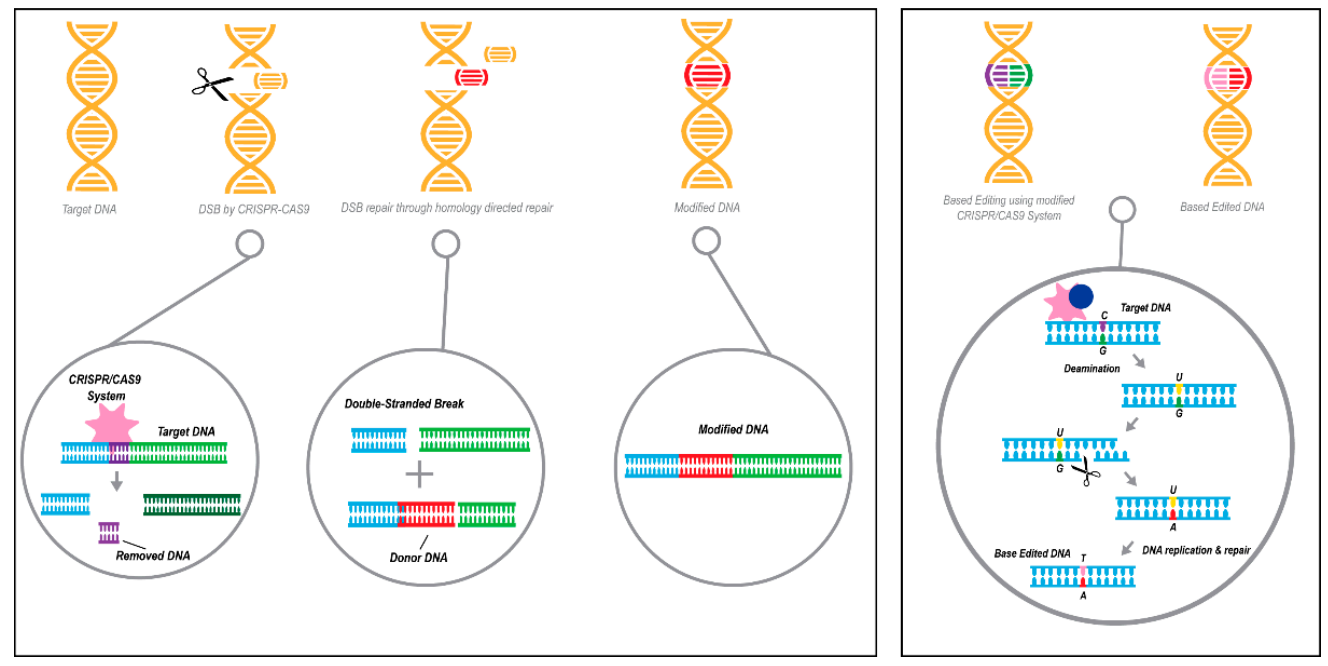

Figure 5. An illustration describing CRISPR/Cas9 technology as gene therapy approaches. Left panel: Gene editing acting on the DNA strand-level by knock-in replacement using the CRISPR-Cas9 system, resulting in targeted genomic deletion followed by homology-directed repair (HDR) with a donor DNA sequence. Orange represents DNA, red donor DNA,) Right panel: Acting on the chemistry of a single DNA base, gene editing by base editing technology utilizes the CRISPR/dCas9 or CRISPR/nickase(n)Cas9 system. Orange represents DNA, the following colors represent the 4 deoxyribonucleic acids: purple $C$, green $G$, pink $T$, red A.

For example, targeted genomic deletion using CRISPR-Cas9 represents a promising a therapeutic approach for the treatment of Leber Congenital Amaurosis 10 (LCA10), a severe retinal dystrophy, in patients with an intronic mutation in CEP290 [101]. CRISPRCas technology has also been used in AD research to target the APP Swedish mutation. The mutation leads to increased $\beta$-secretase cleavage of the amyloid beta precursor protein and thus high levels of $A \beta$. Deleting the mutation in an allele-specific manner by the CRISPR-Cas system reduced the level of the secreted pathogenic $A \beta$, and demonstrated the effectiveness of gene editing as a therapy for familial AD caused by APP dominant mutations [102]. 


\subsubsection{Using CRISPR/Cas Technologies to Target APOE}

Using the CRISPR-Cas gene-editing technology to target the APOE gene has a potential for ameliorating the pathogenic effects of the ApoE4 isoform, despite the current incomplete understanding of the underlying mechanisms that drive its effect. Applying CRISPR-Cas allows the precise editing of the e4 risk allele to the "natural" e3, as these different alleles differ by a single nucleotide rs $429358, T \rightarrow C$. Few studies explore the effect of $A P O E$ gene editing using human induced pluripotent stem cell (hiPSC)-derived models. Characterization of hiPSC-derived neurons with the e4/4 genotype demonstrated higher levels of tau phosphorylation, increased production of $A \beta$, and GABAergic neuron degeneration. Converting e $4 / 4$ to e $3 / 3$ by CRISPR-Cas 9 gene editing rescued these phenotypes. The ability to ameliorate the various AD-related phenotypes suggested that gene editing is a promising therapeutic method for targeting APOE [103]. Another study extended the characterization analyses to different hiPSC-derived brain cell types. This study also utilized CRISPR/Cas9 to convert a hiPSC line from a healthy donor homozygous for the e3 allele into an isogenic hiPSC e4/4 line. The APOE e4 neurons exhibited elevated synaptic activity, increased synapse number, early endosomes, and elevated $\mathrm{A} \beta_{42}$ secretion relative to the isogenic $A P O E$ e3 neurons. APOE e4 astrocytes exhibited impaired clearance of extracellular $\mathrm{A} \beta$ and cholesterol accumulation, and APOEe4 microglia-like cells showed altered morphologies, inflammatory gene activation, and less efficient $\mathrm{A} \beta$ uptake compared to the corresponding APOE e3 cell types. Consistently, converting APOE e4 to APOE e3 was sufficient to attenuate multiple AD-related pathologies in the neurons, astrocytes, and organoids derived from a hiPSCs line obtained from a sporadic AD patient [104].

Base editing is another CRISPR-Cas9-based technology to correct the e4 coding SNP. This technology employs the deactivated Cas9 (dCas9) or nickase Cas9 (nCas9) fused with cytidine deaminase enzyme that allows the conversion of a $\mathrm{C}$ to $\mathrm{T}$ at single-base point mutations without the double-strand DNA backbone breaking, thereby increasing the editing efficiency and reducing additional unwanted insertions and deletions [105]. A study that used $A P O E$ to compare the technologies demonstrated a higher percentage of correction with the base editing approach compared to the conventional gene editing approach with less non-specific events [106]. A recent development in the CRISPR-Cas field, prime-editing [107], may offer a more precise and safe approach with much less undesired effects to correct the APOE e4 coding SNP.

In summary, utilization of CRISPR/Cas9-mediated gene editing approaches can efficiently change the APOE genotype and successfully reverse AD-related phenotypes and impact $A \beta$ aggregation. Altogether, these studies provide a proof-of-concept for the therapeutic potential of this technology in precision medicine for LOAD patients carrying the e4 allele.

\section{Conclusions}

$A P O E$ is a well-established and long-standing genetic risk factor for LOAD; however, it has only recently emerged as a therapeutic target. We suggest that a shift in direction towards targeting APOE in treating LOAD could result in new and effective treatments. The ultimate goal of precision medicine is to enable clinicians to accurately and efficiently identify the most effective preventive or therapeutic intervention for a specific patient. The ability to precisely characterize the $A P O E$ genotypes and determine carriers of the e4 risk allele facilitates the identification of the patients' group that suffers from LOAD due to $A P O E$, and hence will be potentially responsive to a treatment regimen that targets $A P O E$. Thus, $A P O E$ is a prominent example for a target moving forward towards precision medicine in LOAD. New technologies offer the opportunity to develop gene-specific and even isoform/allele-specific therapies, and by that enable the advancement of strategies for precision medicine. Here, we discussed applications of these technologies to target $A P O E$ and specifically strategies directed at the DNA, RNA, and protein levels of APOE. Noteworthy, these technologies, on the other hand, bear significant disadvantage, e.g., a low efficiency and specificity, low stability and solubility, adverse immunoreactivity, and inabil- 
ity to penetrate the blood-brain barrier (BBB) [65,79]. Thus, emerging innovative genomic technologies and delivery techniques may circumvent these limitations. Nonetheless, these approaches can be implemented to other known and perspective candidate gene-targets of LOAD, including dysregulated genes and rare mutations such as TREM2 [108].

Author Contributions: Conceptualization, B.K. and O.C.-F.; writing-original draft preparation, A.Y., B.K. and O.C.-F.; writing-review and editing, A.Y., B.K. and O.C.-F.; visualization, A.Y.; supervision, O.C.-F.; funding, O.C.-F. All authors have read and agreed to the published version of the manuscript.

Funding: This work was funded in part by the National Institutes of Health/National Institute of Aging (NIH/NIA; R01 AG057522 to O.C.-F.).

Institutional Review Board Statement: Not Applicable.

Informed Consent Statement: Not Applicable.

Data Availability Statement: Not Applicable.

Acknowledgments: The authors appreciate the assistance provided by Angela Wei with the graphical scheme presented Figure 2.

Conflicts of Interest: Duke University filed a provisional patent application related to this study.

\section{Abbreviations}

$\begin{array}{ll}\text { AD } & \text { Alzheimer's Disease } \\ \text { LOAD } & \text { Late-onset Alzheimer's Disease } \\ \text { APOE } & \text { Apolipoprotein E } \\ \text { ASO } & \text { Antisense Oligonucleotides } \\ \text { mAB } & \text { Monoclonal Antibodies }\end{array}$

\section{References}

1. Costs of Alzheimer's to Medicare and Medicaid; Alzheimer's Association: Alzheimer's Imipact Movement: Factsheet March 2020; Alzheimer's Association: Chicago, IL, USA, 2020.

2. Sharma, K. Cholinesterase inhibitors as Alzheimer's therapeutics (Review). Mol. Med. Rep. 2019, 20, 1479-1487. [CrossRef] [PubMed]

3. Olivares, D.; Deshpande, V.K.; Shi, Y.; Lahiri, D.K.; Greig, N.H.; Rogers, J.T.; Huang, X. N-methyl D-aspartate (NMDA) receptor antagonists and memantine treatment for Alzheimer's disease, vascular dementia and Parkinson's disease. Curr. Alzheimer Res. 2012, 9, 746-758. [CrossRef] [PubMed]

4. Mawuenyega, K.G.; Kasten, T.; Sigurdson, W.; Bateman, R.J. Amyloid-beta isoform metabolism quantitation by stable isotopelabeled kinetics. Anal. Biochem. 2013, 440, 56-62. [CrossRef] [PubMed]

5. Reitz, C. Toward precision medicine in Alzheimer's disease. Ann. Transl. Med. 2016, 4, 107. [CrossRef]

6. Chiba-Falek, O.; Lutz, M.W. Towards precision medicine in Alzheimer's disease: Deciphering genetic data to establish informative biomarkers. Expert Rev. Precis Med. Drug Dev. 2017, 2, 47-55. [CrossRef]

7. NIA-Funded Active Alzheimer's and Related Dementias Clinical Trials and Studies. National Institute on Aging, 15 July 2020; Volume NIA-Funded Active Alzheimer's and Related Dementias Clinical Trials and Studies. Available online: https:/ / www.nia.nih.gov/research/ongoing-AD-trials\#: \{\}:text=The\%20National\%20Institute\%20on\%20Aging,AD\% 2FADRD \%20that\%20are\%20addressed (accessed on 26 October 2020).

8. Huynh, T.V.; Liao, F.; Francis, C.M.; Robinson, G.O.; Serrano, J.R.; Jiang, H.; Roh, J.; Finn, M.B.; Sullivan, P.M.; Esparza, T.J.; et al. Age-Dependent Effects of apoE Reduction Using Antisense Oligonucleotides in a Model of beta-amyloidosis. Neuron 2017, 96, 1013-1023.e1014. [CrossRef]

9. Brody, D.L.; Holtzman, D.M. Active and passive immunotherapy for neurodegenerative disorders. Annu. Rev. Neurosci. 2008, 31, 175-193. [CrossRef]

10. Kim, J.; Eltorai, A.E.; Jiang, H.; Liao, F.; Verghese, P.B.; Kim, J.; Stewart, F.R.; Basak, J.M.; Holtzman, D.M. Anti-apoE immunotherapy inhibits amyloid accumulation in a transgenic mouse model of Abeta amyloidosis. J. Exp. Med. 2012, 209, $2149-2156$. [CrossRef]

11. Shen, L.; Jia, J. An Overview of Genome-Wide Association Studies in Alzheimer's Disease. Neurosci. Bull. 2016, 32, 183-190. [CrossRef]

12. Huang, Y.; Mahley, R.W. Apolipoprotein E: Structure and function in lipid metabolism, neurobiology, and Alzheimer's diseases. Neurobiol. Dis. 2014, 72 Pt. A, 3-12. [CrossRef]

13. Frieden, C.; Garai, K. Concerning the structure of apoE. Protein Sci. 2013, 22, 1820-1825. [CrossRef] [PubMed] 
14. Frieden, C.; Garai, K. Structural differences between apoE3 and apoE4 may be useful in developing therapeutic agents for Alzheimer's disease. Proc. Natl. Acad. Sci. USA 2012, 109, 8913-8918. [CrossRef] [PubMed]

15. Corder, E.H.; Saunders, A.M.; Strittmatter, W.J.; Schmechel, D.E.; Gaskell, P.C.; Small, G.W.; Roses, A.D.; Haines, J.L.; PericakVance, M.A. Gene dose of apolipoprotein E type 4 allele and the risk of Alzheimer's disease in late onset families. Science 1993, 261, 921-923. [CrossRef] [PubMed]

16. Liu, N.; Zhang, K.; Zhao, H. Haplotype-association analysis. Adv. Genet. 2008, 60, 335-405. [CrossRef] [PubMed]

17. Schmechel, D.E.; Saunders, A.M.; Strittmatter, W.J.; Crain, B.J.; Hulette, C.M.; Joo, S.H.; Pericak-Vance, M.A.; Goldgaber, D.; Roses, A.D. Increased amyloid beta-peptide deposition in cerebral cortex as a consequence of apolipoprotein E genotype in late-onset Alzheimer disease. Proc. Natl. Acad. Sci. USA 1993, 90, 9649-9653. [CrossRef] [PubMed]

18. Saunders, A.M.; Strittmatter, W.J.; Schmechel, D.; George-Hyslop, P.H.; Pericak-Vance, M.A.; Joo, S.H.; Rosi, B.L.; Gusella, J.F.; Crapper-MacLachlan, D.R.; Alberts, M.J.; et al. Association of apolipoprotein E allele epsilon 4 with late-onset familial and sporadic Alzheimer's disease. Neurology 1993, 43, 1467-1472. [CrossRef]

19. Farrer, L.A.; Cupples, L.A.; Haines, J.L.; Hyman, B.; Kukull, W.A.; Mayeux, R.; Myers, R.H.; Pericak-Vance, M.A.; Risch, N.; van Duijn, C.M. Effects of age, sex, and ethnicity on the association between apolipoprotein E genotype and Alzheimer disease. A meta-analysis. APOE and Alzheimer Disease Meta Analysis Consortium. JAMA 1997, 278, 1349-1356. [CrossRef]

20. Reiman, E.M.; Arboleda-Velasquez, J.F.; Quiroz, Y.T.; Huentelman, M.J.; Beach, T.G.; Caselli, R.J.; Chen, Y.; Su, Y.; Myers, A.J.; Hardy, J.; et al. Exceptionally low likelihood of Alzheimer's dementia in APOE2 homozygotes from a 5,000-person neuropathological study. Nat. Commun. 2020, 11, 667. [CrossRef]

21. Gottschalk, W.K.; Mihovilovic, M.; Roses, A.D.; Chiba-Falek, O. The Role of Upregulated APOE in Alzheimer's Disease Etiology. J. Alzheimers Dis. Parkinsonism 2016, 6. [CrossRef]

22. Huang, Y.A.; Zhou, B.; Wernig, M.; Sudhof, T.C. ApoE2, ApoE3, and ApoE4 Differentially Stimulate APP Transcription and Abeta Secretion. Cell 2017, 168, 427-441 e421. [CrossRef]

23. Sen, A.; Nelson, T.J.; Alkon, D.L. ApoE4 and Abeta Oligomers Reduce BDNF Expression via HDAC Nuclear Translocation. J. Neurosci. 2015, 35, 7538-7551. [CrossRef] [PubMed]

24. Theendakara, V.; Patent, A.; Peters Libeu, C.A.; Philpot, B.; Flores, S.; Descamps, O.; Poksay, K.S.; Zhang, Q.; Cailing, G.; Hart, M.; et al. Neuroprotective Sirtuin ratio reversed by ApoE4. Proc. Natl. Acad. Sci. USA 2013, 110, 18303-18308. [CrossRef] [PubMed]

25. Theendakara, V.; Peters-Libeu, C.A.; Spilman, P.; Poksay, K.S.; Bredesen, D.E.; Rao, R.V. Direct Transcriptional Effects of Apolipoprotein E. J. Neurosci. 2016, 36, 685-700. [CrossRef] [PubMed]

26. Min, S.W.; Cho, S.H.; Zhou, Y.; Schroeder, S.; Haroutunian, V.; Seeley, W.W.; Huang, E.J.; Shen, Y.; Masliah, E.; Mukherjee, C.; et al. Acetylation of tau inhibits its degradation and contributes to tauopathy. Neuron 2010,67, 953-966. [CrossRef]

27. Tambini, M.D.; Pera, M.; Kanter, E.; Yang, H.; Guardia-Laguarta, C.; Holtzman, D.; Sulzer, D.; Area-Gomez, E.; Schon, E.A. ApoE4 upregulates the activity of mitochondria-associated ER membranes. EMBO Rep. 2016, 17, 27-36. [CrossRef]

28. Hatters, D.M.; Zhong, N.; Rutenber, E.; Weisgraber, K.H. Amino-terminal domain stability mediates apolipoprotein E aggregation into neurotoxic fibrils. J. Mol. Biol. 2006, 361, 932-944. [CrossRef]

29. Harold, D.; Abraham, R.; Hollingworth, P.; Sims, R.; Gerrish, A.; Hamshere, M.L.; Pahwa, J.S.; Moskvina, V.; Dowzell, K.; Williams, A.; et al. Genome-wide association study identifies variants at CLU and PICALM associated with Alzheimer's disease. Nat. Genet. 2009, 41, 1088-1093. [CrossRef]

30. Lambert, J.C.; Heath, S.; Even, G.; Campion, D.; Sleegers, K.; Hiltunen, M.; Combarros, O.; Zelenika, D.; Bullido, M.J.; Tavernier, B.; et al. Genome-wide association study identifies variants at CLU and CR1 associated with Alzheimer's disease. Nat. Genet. 2009, 41, 1094-1099. [CrossRef]

31. Heinzen, E.L.; Need, A.C.; Hayden, K.M.; Chiba-Falek, O.; Roses, A.D.; Strittmatter, W.J.; Burke, J.R.; Hulette, C.M.; Welsh-Bohmer, K.A.; Goldstein, D.B. Genome-wide scan of copy number variation in late-onset Alzheimer's disease. J. Alzheimers Dis. 2010, 19, 69-77. [CrossRef]

32. Kamboh, M.I.; Barmada, M.M.; Demirci, F.Y.; Minster, R.L.; Carrasquillo, M.M.; Pankratz, V.S.; Younkin, S.G.; Saykin, A.J.; Sweet, R.A.; Alzheimer's Disease Neuroimaging Initiative; et al. Genome-wide association analysis of age-at-onset in Alzheimer's disease. Mol. Psychiatry 2012, 17, 1340-1346. [CrossRef]

33. Kamboh, M.I.; Demirci, F.Y.; Wang, X.; Minster, R.L.; Carrasquillo, M.M.; Pankratz, V.S.; Younkin, S.G.; Saykin, A.J.; Jun, G.; Alzheimer's Disease Neuroimaging Initiative; et al. Genome-wide association study of Alzheimer's disease. Transl. Psychiatry 2012, 2, e117. [CrossRef] [PubMed]

34. Seshadri, S.; Fitzpatrick, A.L.; Ikram, M.A.; DeStefano, A.L.; Gudnason, V.; Boada, M.; Bis, J.C.; Smith, A.V.; Carassquillo, M.M.; Lambert, J.C.; et al. Genome-wide analysis of genetic loci associated with Alzheimer disease. JAMA 2010, 303, $1832-1840$. [CrossRef]

35. Kunkle, B.W.; Grenier-Boley, B.; Sims, R.; Bis, J.C.; Damotte, V.; Naj, A.C.; Boland, A.; Vronskaya, M.; van der Lee, S.J.; Amlie-Wolf, A.; et al. Genetic meta-analysis of diagnosed Alzheimer's disease identifies new risk loci and implicates Abeta, tau, immunity and lipid processing. Nat. Genet. 2019, 51, 414-430. [CrossRef] [PubMed]

36. Lambert, J.C.; Ibrahim-Verbaas, C.A.; Harold, D.; Naj, A.C.; Sims, R.; Bellenguez, C.; DeStafano, A.L.; Bis, J.C.; Beecham, G.W.; Grenier-Boley, B.; et al. Meta-analysis of 74,046 individuals identifies 11 new susceptibility loci for Alzheimer's disease. Nat. Genet. 2013, 45, 1452-1458. [CrossRef] [PubMed] 
37. Coon, K.D.; Myers, A.J.; Craig, D.W.; Webster, J.A.; Pearson, J.V.; Lince, D.H.; Zismann, V.L.; Beach, T.G.; Leung, D.; Bryden, L.; et al. A high-density whole-genome association study reveals that APOE is the major susceptibility gene for sporadic late-onset Alzheimer's disease. J. Clin. Psychiatry 2007, 68, 613-618. [CrossRef] [PubMed]

38. Bekris, L.M.; Lutz, F.; Yu, C.E. Functional analysis of APOE locus genetic variation implicates regional enhancers in the regulation of both TOMM40 and APOE. J. Hum. Genet. 2012, 57, 18-25. [CrossRef]

39. Lescai, F.; Chiamenti, A.M.; Codemo, A.; Pirazzini, C.; D’Agostino, G.; Ruaro, C.; Ghidoni, R.; Benussi, L.; Galimberti, D.; Esposito, F.; et al. An APOE haplotype associated with decreased epsilon4 expression increases the risk of late onset Alzheimer's disease. J. Alzheimers Dis. 2011, 24, 235-245. [CrossRef]

40. Xin, X.Y.; Ding, J.Q.; Chen, S.D. Apolipoprotein E promoter polymorphisms and risk of Alzheimer's disease: Evidence from meta-analysis. J. Alzheimers Dis. 2010, 19, 1283-1294. [CrossRef]

41. Laws, S.M.; Hone, E.; Gandy, S.; Martins, R.N. Expanding the association between the APOE gene and the risk of Alzheimer's disease: Possible roles for APOE promoter polymorphisms and alterations in APOE transcription. J. Neurochem. 2003, 84, 1215-1236. [CrossRef]

42. Nicodemus, K.K.; Stenger, J.E.; Schmechel, D.E.; Welsh-Bohmer, K.A.; Saunders, A.M.; Roses, A.D.; Gilbert, J.R.; Vance, J.M.; Haines, J.L.; Pericak-Vance, M.A.; et al. Comprehensive association analysis of APOE regulatory region polymorphisms in Alzheimer disease. Neurogenetics 2004, 5, 201-208. [CrossRef]

43. Lambert, J.C.; Araria-Goumidi, L.; Myllykangas, L.; Ellis, C.; Wang, J.C.; Bullido, M.J.; Harris, J.M.; Artiga, M.J.; Hernandez, D.; Kwon, J.M.; et al. Contribution of APOE promoter polymorphisms to Alzheimer's disease risk. Neurology 2002, 59, 59-66. [CrossRef] [PubMed]

44. Tycko, B.; Lee, J.H.; Ciappa, A.; Saxena, A.; Li, C.M.; Feng, L.; Arriaga, A.; Stern, Y.; Lantigua, R.; Shachter, N.; et al. APOE and APOC1 promoter polymorphisms and the risk of Alzheimer disease in African American and Caribbean Hispanic individuals. Arch. Neurol. 2004, 61, 1434-1439. [CrossRef] [PubMed]

45. Yu, C.E.; Seltman, H.; Peskind, E.R.; Galloway, N.; Zhou, P.X.; Rosenthal, E.; Wijsman, E.M.; Tsuang, D.W.; Devlin, B.; Schellenberg, G.D. Comprehensive analysis of APOE and selected proximate markers for late-onset Alzheimer's disease: Patterns of linkage disequilibrium and disease/marker association. Genomics 2007, 89, 655-665. [CrossRef] [PubMed]

46. Linnertz, C.; Anderson, L.; Gottschalk, W.; Crenshaw, D.; Lutz, M.W.; Allen, J.; Saith, S.; Mihovilovic, M.; Burke, J.R.; WelshBohmer, K.A.; et al. The cis-regulatory effect of an Alzheimer's disease-associated poly-T locus on expression of TOMM40 and apolipoprotein E genes. Alzheimers Dement. 2014, 10, 541-551. [CrossRef]

47. Zarow, C.; Victoroff, J. Increased apolipoprotein E mRNA in the hippocampus in Alzheimer disease and in rats after entorhinal cortex lesioning. Exp. Neurol. 1998, 149, 79-86. [CrossRef]

48. Matsui, T.; Ingelsson, M.; Fukumoto, H.; Ramasamy, K.; Kowa, H.; Frosch, M.P.; Irizarry, M.C.; Hyman, B.T. Expression of APP pathway mRNAs and proteins in Alzheimer's disease. Brain Res. 2007, 1161, 116-123. [CrossRef]

49. Akram, A.; Schmeidler, J.; Katsel, P.; Hof, P.R.; Haroutunian, V. Association of ApoE and LRP mRNA levels with dementia and AD neuropathology. Neurobiol. Aging 2012, 33, 628 e1. [CrossRef]

50. Grubman, A.; Chew, G.; Ouyang, J.F.; Sun, G.; Choo, X.Y.; McLean, C.; Simmons, R.K.; Buckberry, S.; Vargas-Landin, D.B.; Poppe, D.; et al. A single-cell atlas of entorhinal cortex from individuals with Alzheimer's disease reveals cell-type-specific gene expression regulation. Nat. Neurosci. 2019, 22, 2087-2097. [CrossRef]

51. Mathys, H.; Davila-Velderrain, J.; Peng, Z.; Gao, F.; Mohammadi, S.; Young, J.Z.; Menon, M.; He, L.; Abdurrob, F.; Jiang, X.; et al. Single-cell transcriptomic analysis of Alzheimer's disease. Nature 2019, 570, 332-337. [CrossRef]

52. Hashemiaghdam, A.; Mroczek, M. Microglia heterogeneity and neurodegeneration: The emerging paradigm of the role of immunity in Alzheimer's disease. J. Neuroimmunol. 2020, 341, 577185. [CrossRef]

53. Zheng, J.Y.; Sun, J.; Ji, C.M.; Shen, L.; Chen, Z.J.; Xie, P.; Sun, Y.Z.; Yu, R.T. Selective deletion of apolipoprotein E in astrocytes ameliorates the spatial learning and memory deficits in Alzheimer's disease (APP/PS1) mice by inhibiting TGF-beta/Smad2/STAT3 signaling. Neurobiol. Aging 2017, 54, 112-132. [CrossRef] [PubMed]

54. Bien-Ly, N.; Gillespie, A.K.; Walker, D.; Yoon, S.Y.; Huang, Y. Reducing human apolipoprotein E levels attenuates age-dependent Abeta accumulation in mutant human amyloid precursor protein transgenic mice. J. Neurosci. 2012, 32, 4803-4811. [CrossRef] [PubMed]

55. Kim, J.; Jiang, H.; Park, S.; Eltorai, A.E.; Stewart, F.R.; Yoon, H.; Basak, J.M.; Finn, M.B.; Holtzman, D.M. Haploinsufficiency of human APOE reduces amyloid deposition in a mouse model of amyloid-beta amyloidosis. J. Neurosci. 2011, 31, 18007-18012. [CrossRef] [PubMed]

56. Foraker, J.; Millard, S.P.; Leong, L.; Thomson, Z.; Chen, S.; Keene, C.D.; Bekris, L.M.; Yu, C.E. The APOE Gene is Differentially Methylated in Alzheimer's Disease. J. Alzheimers Dis. 2015, 48, 745-755. [CrossRef]

57. Shao, Y.; Shaw, M.; Todd, K.; Khrestian, M.; D'Aleo, G.; Barnard, P.J.; Zahratka, J.; Pillai, J.; Yu, C.E.; Keene, C.D.; et al. DNA methylation of TOMM40-APOE-APOC2 in Alzheimer's disease. J. Hum. Genet. 2018, 63, 459-471. [CrossRef]

58. Tulloch, J.; Leong, L.; Thomson, Z.; Chen, S.; Lee, E.G.; Keene, C.D.; Millard, S.P.; Yu, C.E. Glia-specific APOE epigenetic changes in the Alzheimer's disease brain. Brain Res. 2018, 1698, 179-186. [CrossRef]

59. Mancera-Paez, O.; Estrada-Orozco, K.; Mahecha, M.F.; Cruz, F.; Bonilla-Vargas, K.; Sandoval, N.; Guerrero, E.; Salcedo-Tacuma, D.; Melgarejo, J.D.; Vega, E.; et al. Differential Methylation in APOE (Chr19; Exon Four; from 44,909,188 to 44,909,373/hg38) and Increased Apolipoprotein E Plasma Levels in Subjects with Mild Cognitive Impairment. Int J. Mol. Sci. 2019, 20, 1394. [CrossRef] 
60. Babenko, V.N.; Afonnikov, D.A.; Ignatieva, E.V.; Klimov, A.V.; Gusev, F.E.; Rogaev, E.I. Haplotype analysis of APOE intragenic SNPs. BMC Neurosci. 2018, 19, 16. [CrossRef]

61. Li, Z.; Shue, F.; Zhao, N.; Shinohara, M.; Bu, G. APOE2: Protective mechanism and therapeutic implications for Alzheimer's disease. Mol. Neurodegener. 2020, 15, 63. [CrossRef]

62. Serrano-Pozo, A.; Das, S.; Hyman, B.T. APOE and Alzheimer's disease: Advances in genetics, pathophysiology, and therapeutic approaches. Lancet Neurol. 2021, 20, 68-80. [CrossRef]

63. Rinaldi, C.; Wood, M.J.A. Antisense oligonucleotides: The next frontier for treatment of neurological disorders. Nat. Rev. Neurol. 2018, 14, 9-21. [CrossRef] [PubMed]

64. Scoles, D.R.; Minikel, E.V.; Pulst, S.M. Antisense oligonucleotides: A primer. Neurol. Genet. 2019, 5, e323. [CrossRef] [PubMed]

65. Schoch, K.M.; Miller, T.M. Antisense Oligonucleotides: Translation from Mouse Models to Human Neurodegenerative Diseases. Neuron 2017, 94, 1056-1070. [CrossRef] [PubMed]

66. Gorbatyuk, O.S.; Li, S.; Nash, K.; Gorbatyuk, M.; Lewin, A.S.; Sullivan, L.F.; Mandel, R.J.; Chen, W.; Meyers, C.; Manfredsson, F.P.; et al. In vivo RNAi-mediated alpha-synuclein silencing induces nigrostriatal degeneration. Mol. Ther. J. Am. Soc. Gene Ther. 2010, 18, 1450-1457. [CrossRef]

67. Khodr, C.E.; Sapru, M.K.; Pedapati, J.; Han, Y.; West, N.C.; Kells, A.P.; Bankiewicz, K.S.; Bohn, M.C. An alpha-synuclein AAV gene silencing vector ameliorates a behavioral deficit in a rat model of Parkinson's disease, but displays toxicity in dopamine neurons. Brain Res. 2011, 1395, 94-107. [CrossRef]

68. Frank, D.E.; Schnell, F.J.; Akana, C.; El-Husayni, S.H.; Desjardins, C.A.; Morgan, J.; Charleston, J.S.; Sardone, V.; Domingos, J.; Dickson, G.; et al. Increased dystrophin production with golodirsen in patients with Duchenne muscular dystrophy. Neurology 2020, 94, e2270-e2282. [CrossRef]

69. Mercuri, E.; Darras, B.T.; Chiriboga, C.A.; Day, J.W.; Campbell, C.; Connolly, A.M.; Iannaccone, S.T.; Kirschner, J.; Kuntz, N.L.; Saito, K.; et al. Nusinersen versus Sham Control in Later-Onset Spinal Muscular Atrophy. N. Engl. J. Med. 2018, 378, 625-635. [CrossRef]

70. Wild, E.J.; Tabrizi, S.J. Therapies targeting DNA and RNA in Huntington's disease. Lancet Neurol. 2017, 16, 837-847. [CrossRef]

71. van Roon-Mom, W.M.C.; Roos, R.A.C.; de Bot, S.T. Dose-Dependent Lowering of Mutant Huntingtin Using Antisense Oligonucleotides in Huntington Disease Patients. Nucleic Acid Ther. 2018, 28, 59-62. [CrossRef]

72. McCampbell, A.; Cole, T.; Wegener, A.J.; Tomassy, G.S.; Setnicka, A.; Farley, B.J.; Schoch, K.M.; Hoye, M.L.; Shabsovich, M.; Sun, L.; et al. Antisense oligonucleotides extend survival and reverse decrement in muscle response in ALS models. J. Clin. Investig. 2018, 128, 3558-3567. [CrossRef]

73. Miller, T.M.; Pestronk, A.; David, W.; Rothstein, J.; Simpson, E.; Appel, S.H.; Andres, P.L.; Mahoney, K.; Allred, P.; Alexander, K.; et al. An antisense oligonucleotide against SOD1 delivered intrathecally for patients with SOD1 familial amyotrophic lateral sclerosis: A phase 1, randomised, first-in-man study. Lancet Neurol. 2013, 12, 435-442. [CrossRef]

74. Grainger, D.W. Controlled-release and local delivery of therapeutic antibodies. Expert Opin. Biol. Ther. 2004, 4, 1029-1044. [CrossRef] [PubMed]

75. Bakker, J.M.; Bleeker, W.K.; Parren, P.W. Therapeutic antibody gene transfer: An active approach to passive immunity. Mol. Ther. 2004, 10, 411-416. [CrossRef] [PubMed]

76. Hollevoet, K.; Declerck, P.J. State of play and clinical prospects of antibody gene transfer. J. Transl. Med. 2017, 15, 131. [CrossRef] [PubMed]

77. Williams, T.; Borchelt, D.R.; Chakrabarty, P. Therapeutic approaches targeting Apolipoprotein E function in Alzheimer's disease. Mol. Neurodegener. 2020, 15, 8. [CrossRef]

78. Guijarro-Munoz, I.; Compte, M.; Alvarez-Vallina, L.; Sanz, L. Antibody gene therapy: Getting closer to clinical application? Curr Gene Ther. 2013, 13, 282-290. [CrossRef]

79. Yu, Y.J.; Watts, R.J. Developing therapeutic antibodies for neurodegenerative disease. Neurotherapeutics 2013, 10, 459-472. [CrossRef]

80. Samaranayake, H.; Wirth, T.; Schenkwein, D.; Raty, J.K.; Yla-Herttuala, S. Challenges in monoclonal antibody-based therapies. Ann. Med. 2009, 41, 322-331. [CrossRef]

81. Zheng, D. Antibody gene therapy: An attractive approach for the treatment of cancers and other chronic diseases. Cell Res. 2007, 17, 303-306. [CrossRef]

82. Kotsovilis, S.; Andreakos, E. Therapeutic human monoclonal antibodies in inflammatory diseases. Methods Mol. Biol. 2014, 1060, 37-59. [CrossRef]

83. Spillantini, M.G.; Crowther, R.A.; Jakes, R.; Hasegawa, M.; Goedert, M. alpha-Synuclein in filamentous inclusions of Lewy bodies from Parkinson's disease and dementia with lewy bodies. Proc. Natl. Acad. Sci. USA 1998, 95, 6469-6473. [CrossRef] [PubMed]

84. Jankovic, J.; Goodman, I.; Safirstein, B.; Marmon, T.K.; Schenk, D.B.; Koller, M.; Zago, W.; Ness, D.K.; Griffith, S.G.; Grundman, M.; et al. Safety and Tolerability of Multiple Ascending Doses of PRX002/RG7935, an Anti-alpha-Synuclein Monoclonal Antibody, in Patients with Parkinson Disease: A Randomized Clinical Trial. JAMA Neurol. 2018, 75, 1206-1214. [CrossRef] [PubMed]

85. A Study to Evaluate the Efficacy of Prasinezumab (RO7046015/PRX002) in Participants with Early Parkinson's Disease. Available online: https: / / ClinicalTrials.gov / show / NCT03100149 (accessed on 26 January 2021).

86. Evaluating the Efficacy, Safety, Pharmacokinetics, and Pharmacodynamics of BIIB054 in Participants With Parkinson's Disease. Available online: https: / / ClinicalTrials.gov / show / NCT03318523 (accessed on 26 January 2021). 
87. Brys, M.; Fanning, L.; Hung, S.; Ellenbogen, A.; Penner, N.; Yang, M.; Welch, M.; Koenig, E.; David, E.; Fox, T.; et al. Randomized phase I clinical trial of anti-alpha-synuclein antibody BIIB054. Mov. Disord. 2019, 34, 1154-1163. [CrossRef]

88. Siemers, E.R.; Friedrich, S.; Dean, R.A.; Gonzales, C.R.; Farlow, M.R.; Paul, S.M.; Demattos, R.B. Safety and changes in plasma and cerebrospinal fluid amyloid beta after a single administration of an amyloid beta monoclonal antibody in subjects with Alzheimer disease. Clin. Neuropharmacol. 2010, 33, 67-73. [CrossRef] [PubMed]

89. Progress of Mild Alzheimer's Disease in Participants on Solanezumab Versus Placebo. Available online: https:/ /ClinicalTrials. gov / show / NCT01900665 (accessed on 26 January 2021).

90. A Study to Evaluate the Efficacy and Safety of MABT5102A in Patients with Mild to Moderate Alzheimer's Disease (ABBY). Available online: https: / /ClinicalTrials.gov/show / NCT01343966 (accessed on 26 January 2021).

91. A Study Evaluating the Efficacy and Safety of Crenezumab Versus Placebo in Participants with Prodromal to Mild Alzheimer's Disease (AD). Available online: https: / ClinicalTrials.gov/show / NCT02670083 (accessed on 26 January 2021).

92. Update on FDA Advisory Committee's Meeting on Aducanumab in Alzheimer's Disease; Biogen: Cambridge, MA, USA, 2020.

93. Arndt, J.W.; Qian, F.; Smith, B.A.; Quan, C.; Kilambi, K.P.; Bush, M.W.; Walz, T.; Pepinsky, R.B.; Bussiere, T.; Hamann, S.; et al. Structural and kinetic basis for the selectivity of aducanumab for aggregated forms of amyloid-beta. Sci. Rep. 2018, 8, 6412. [CrossRef]

94. Biogen Plans Regulatory Filing for Aducanumab in Alzheimer's Disease Based on New Analysis of Larger Dataset from Phase 3 Studies; Biogen: Cambridge, MA, USA, 2019.

95. Bryne, J. Biogen 'Continues to Work' with FDA on Alzheimer's Drug Candidate Despite Regulatory Setback. 2020. Available online: https:/ / www.biopharma-reporter.com/Article/2020/2011/2010/Biogen-continues-to-work-with-FDA-on-Alzheimers-drug-candidate-despite-regulatory-setback (accessed on 26 January 2021).

96. Liao, F.; Hori, Y.; Hudry, E.; Bauer, A.Q.; Jiang, H.; Mahan, T.E.; Lefton, K.B.; Zhang, T.J.; Dearborn, J.T.; Kim, J.; et al. Anti-ApoE antibody given after plaque onset decreases Abeta accumulation and improves brain function in a mouse model of Abeta amyloidosis. J. Neurosci. 2014, 34, 7281-7292. [CrossRef]

97. Luz, I.; Liraz, O.; Michaelson, D.M. An Anti-apoE4 Specific Monoclonal Antibody Counteracts the Pathological Effects of apoE4 In Vivo. Curr. Alzheimer Res. 2016, 13, 918-929. [CrossRef]

98. Liao, F.; Li, A.; Xiong, M.; Bien-Ly, N.; Jiang, H.; Zhang, Y.; Finn, M.B.; Hoyle, R.; Keyser, J.; Lefton, K.B.; et al. Targeting of nonlipidated, aggregated apoE with antibodies inhibits amyloid accumulation. J. Clin. Investig. 2018, 128, 2144-2155. [CrossRef]

99. Li, H.; Yang, Y.; Hong, W.; Huang, M.; Wu, M.; Zhao, X. Applications of genome editing technology in the targeted therapy of human diseases: Mechanisms, advances and prospects. Signal. Transduct. Target. Ther. 2020, 5, 1. [CrossRef]

100. Doudna, J.A. The promise and challenge of therapeutic genome editing. Nature 2020, 578, 229-236. [CrossRef]

101. Ruan, G.X.; Barry, E.; Yu, D.; Lukason, M.; Cheng, S.H.; Scaria, A. CRISPR/Cas9-Mediated Genome Editing as a Therapeutic Approach for Leber Congenital Amaurosis 10. Mol. Ther. 2017, 25, 331-341. [CrossRef] [PubMed]

102. Gyorgy, B.; Loov, C.; Zaborowski, M.P.; Takeda, S.; Kleinstiver, B.P.; Commins, C.; Kastanenka, K.; Mu, D.; Volak, A.; Giedraitis, V.; et al. CRISPR/Cas9 Mediated Disruption of the Swedish APP Allele as a Therapeutic Approach for Early-Onset Alzheimer's Disease. Mol. Ther. Nucleic Acids 2018, 11, 429-440. [CrossRef] [PubMed]

103. Wang, C.; Najm, R.; Xu, Q.; Jeong, D.E.; Walker, D.; Balestra, M.E.; Yoon, S.Y.; Yuan, H.; Li, G.; Miller, Z.A.; et al. Gain of toxic apolipoprotein E4 effects in human iPSC-derived neurons is ameliorated by a small-molecule structure corrector. Nat. Med. 2018, 24, 647-657. [CrossRef] [PubMed]

104. Lin, Y.T.; Seo, J.; Gao, F.; Feldman, H.M.; Wen, H.L.; Penney, J.; Cam, H.P.; Gjoneska, E.; Raja, W.K.; Cheng, J.; et al. APOE4 Causes Widespread Molecular and Cellular Alterations Associated with Alzheimer's Disease Phenotypes in Human iPSC-Derived Brain Cell Types. Neuron 2018, 98, 1294. [CrossRef]

105. Ravindran, S. Got mutation? 'Base editors' fix genomes one nucleotide at a time. Nature 2019, 575, 553-555. [CrossRef]

106. Komor, A.C.; Kim, Y.B.; Packer, M.S.; Zuris, J.A.; Liu, D.R. Programmable editing of a target base in genomic DNA without double-stranded DNA cleavage. Nature 2016, 533, 420-424. [CrossRef]

107. Schene, I.F.; Joore, I.P.; Oka, R.; Mokry, M.; van Vugt, A.H.M.; van Boxtel, R.; van der Doef, H.P.J.; van der Laan, L.J.W.; Verstegen, M.M.A.; van Hasselt, P.M.; et al. Prime editing for functional repair in patient-derived disease models. Nat. Commun. 2020, 11, 5352. [CrossRef]

108. Guerreiro, R.; Bilgic, B.; Guven, G.; Bras, J.; Rohrer, J.; Lohmann, E.; Hanagasi, H.; Gurvit, H.; Emre, M. Novel compound heterozygous mutation in TREM2 found in a Turkish frontotemporal dementia-like family. Neurobiol. Aging 2013, 34, 2890. e1. [CrossRef] 